\title{
The Shifting of Business Activities during the COVID-19 Pandemic: Does Social Media Marketing Matter?*
}

\author{
Tundung Subali PATMA ${ }^{1}$, Ludi Wishnu WARDANA², Agus WIBOWO ${ }^{3}$, Bagus Shandy NARMADITYA ${ }^{4}$
}

Received: September 01, 2020 Revised: October 26, 2020 Accepted: November 05, 2020

\begin{abstract}
The implementation of physical or social distancing during the Covid-19 pandemic has an implication on the shifting of conventional to online business activities. This study aims to explore how financial support, perceived benefits, external pressure determine social media marketing as well as understanding the role of internet and e-business technology (IEBT) that occurs in this relationship. This study adopted a quantitative study with Structural Equation Modeling (SEM)-based variance Partial Least Square (PLS), which aims to enhance understanding of the relationship between variables. The surveyed population of this study came from 123 small- and medium-sized enterprise (SME) owners in East Java of Indonesia, using an online survey and selected with the convenience random sampling method. The findings of this study indicated that the perceived benefits and external pressure have a positive effect on the adoption of IEBT. However, financial support failed in explaining SMEs' adoption of IEBT. This study confirmed that the adoption of IEBT has successfully mediated the influence of financial support, perceived benefits, and external pressure on social media marketing. Despite the samples solely collected from East Java, this study is the first step in research related to the social media marketing in SMEs in Indonesia.
\end{abstract}

Keywords: External Pressure, Financial Support, Internet and e-Business Technology, Perceived Benefits, Social Media Marketing

JEL Classification Code: D80, D21, G20

\section{Introduction}

The Covid-19 pandemic has been a global challenge. The governments throughout the world have attempted to response by providing strict regulations to diminish the

\footnotetext{
*Acknowledgements:

We are grateful to anonymous referees and editor of the journal for their valuable comments and suggestions an attempt to enhance the quality of article.

${ }^{1}$ First Author and Corresponding Author. Department of Business Administration, Politeknik Negeri Malang, Indonesia [Postal Address: Jl. Soekarno Hatta No. 9, Jatimulyo, Malang, East Java, 65141, Indonesia] Email: tundung.subali@polinema.ac.id

${ }^{2}$ Department of Business and Management Education, Faculty of Economics, Universitas Negeri Malang, Indonesia.

Email: ludi.wishnu.fe@um.ac.id

${ }^{3}$ Department of Economic Education, Faculty of Economics, Universitas Negeri Jakarta, Indonesia. Email: agus-wibowo@unj.ac.id

${ }^{4}$ Department of Economic Education, Faculty of Economics, Universitas

Negeri Malang, Indonesia. Email: bagus.shandy.fe@um.ac.id

(c) Copyright: The Author(s)

This is an Open Access article distributed under the terms of the Creative Commons Attribution Non-Commercial License (https://creativecommons.org/licenses/by-nc/4.0/) which permits unrestricted non-commercial use, distribution, and reproduction in any medium, provided the original work is properly cited.
}

spread of the virus, such as suggesting to conduct activities from home (work, study, worship) as well as implementing the physical or social distancing policy. As a consequence, businesses, especially SMEs, have suffered from the diminishing demand (Nicola et al., 2020). SMEs have constraints to strike back at the risks engaged and pay the prices of decreasing business activities, confronting the lack of funds, liquidity, workers, buyers, and technology adoption (Bayramov et al., 2019; Sumiati, 2020).

Dealing with these issues, SMEs should redesign their business strategy to survive during the Covid-19 pandemic by using the Internet. Since the transition from conventional to online business activities, social media marketing (SMM) has gained attention in the business domain today. This is driven by companies leveraging the power of SMM as a strategic tool to increase company value, profitability, and competitive advantage (Aral \& Weill, 2007). Recent studies (Ahmad et al., 2018, Bailey, 2019; Chatterjee \& Kar, 2020) have shown that SMM is a workable instrument that can help businesses to attract customers. However, SMM adoption rates by SMEs remained low due to lack of knowledge on how to utilize the benefits of technology (Dekker et al., 2018; Nguyen \& Luu, 2020). 
The presence of the Internet for both small- and largescale of businesses can create opportunities to enhance ventures' profit (Chang \& Cheung, 2001; Weisberg et al., 2011). Therefore, adopting Internet and e-business technology (IEBT), for instance, email, online transaction, and web page, can support business primarily during the Covid-19 pandemic situation. Sadowski et al. (2002) argued that in creating a new bond with the Internet, new users need to embrace a new set of related technologies. According to Chatterjee and Kumar (2020), IEBT is being part of facilitating conditions (FCO) that influence SMM. FCO can be interpreted as the extent to which people perceive the infrastructure in the form of technology that supports them (Venkatesh et al., 2003: Chatterjee \& Kar, 2020). Previous studies by Hofsted (1997); Hung and Lai (2015) concluded that facilitation conditions have a significant effect on innovative technology adoption behavior. Besides, SMEs will not hesitate to adopt technology in marketing if the infrastructure also provides support.

Additionally, Ifinedo (2011) remarked that financial support (FS) is part of the environmental context that affects IEBT. In the constellation delineated by Ifinedo (2011); Chong and Pervan (2007), financial support (FS), perceived benefits (PB), and external pressure (EP) can explain IEBT. The contribution of this study is threefold: first, this study provides practical findings related to how SMEs pay attention to dominant factors such as financial support (FS), perceived benefits (PB), and external pressure (EP) on the use of IEBT. By paying attention to these factors, SMEs can be useful in applying IEBT. Second, this study provides valuable input on how effective marketing strategies are during the Covid-19 pandemic, especially finding that the IEBT variable affects SMM. Third, the engagement of the SMM variable is the first in the Indonesian context and highly relevant in the context of SMEs' efforts to survive in the Covid-19 pandemic.

\section{Literature Review}

\subsection{Financial Support}

The growing body of works has shown that finance in support of SMEs plays an essential role in driving economic growth (Ramadani et al., 2016; Ramayah et al., 2016). As the principal agent of employment, SMEs are the focus of many governments' economic policy due to their contribution to economic growth through increased job creation (Chege \& Wang, 2020). Bank loan behavior of SMEs is considered positively related to the business cycle. Banks will thus be reluctant to lend to SMEs that suffer from a lack of collateral during the economic recession, and SMEs funding faces limitations due to SMEs procyclicity (Yoshino et al., 2016). Most previous studies have shown that the effect of financial support can lead to differences in future outcomes, due to the intensity of capital, current business cycles, and different financial market conditions (Alshehhi et al., 2018; Moreira, 2018). Previously, researchers have also studied the effectiveness of government through related departments, banks or soft creditors toward SMEs (Hirsch et al., 2018).

H1: Financial support has a positive impact on adoption of IEBT

\subsection{Perceived Benefits}

The primary goal of business organizations aims to maximize profits and financial gain (Ramakrishnan et al., 2015). As a consequence, decision-makers are determined to use cost-benefit analysis (Cordes, 2017). Additionally, environmental initiatives are expected to comply with these general rules, for instance, businesses whose advantages should be derived from green initiatives before engaging in profit-generating initiatives (Ann et al., 2006). However, this situation is not occurring since companies strive to accomplish a competitive advantage and become market leaders. In fact, they can generate profit given environmental and social aspects (Ramakrishnan et al., 2015). Organizational adoption of green purchasing (GP) practices will enhance if they can determine these will result in particular financial and operational advantages (BareselBofinger et al., 2006).

H2: Perceived benefits has a positive impact on adoption of IEBT

\subsection{External Pressure}

The environmental context within the framework of Walker et al. (2016) consisted of external pressure. The external pressure is related to the impact received by SMEs from outside sources. The literature recognizes three main external pressure including competition, supplier and customer pressure (Kula \& Tatoglu, 2003). The competitive pressure will drive the penetration of IS innovation that has been considered to be one of the greater predictors of the Internet innovation in a business (Chong \& Pervan, 2007; Poon \& Swatman, 1999). This can come from suppliers, customers, government, industry, and dependence on companies that use e-commerce. Rogers (2010) theorized that the adoption of technology is social in nature, influenced by organizational processes that lead to social and organizational stress. Several prior studies by Chelliah et al. (2017); Kumar et al. (2017); Auwal et al. (2020); Testa et al. (2017) identified external pressures as determinants of information technology adoption. 
H3: External pressure has a positive impact on adoption of IEBT

\subsection{Adoption of Internet and e-Business Technologies (IEBT)}

Innovation adoption is linked with various factors, including organizational, environmental, and technological. The technology-organization-environment (TOE) is an integrative scheme that combines technological characteristics, contingent organizational factors, and elements of the macro environment (Tornatzky \& Fleischer, 1990; Li et al., 2010). SMEs realize that innovation plays a significant role and enhance benefits over existing practices and systems. Therefore, it is expected that the adoption of Internet and e-business technology will impact on the performance (Ifinedo, 2011). The indirect and direct advantages from the adoption of IEBT can be seen in maximizing existing sources, and it can impact the profit. Numerous works by Abd Rahman et al. (2017); Mehrtens et al. (2001); Müller and Voig (2018) have reported that relative benefits are strong predictors of IEBT and related technologies in SMEs. Notably, the acceptance of IEBT by SMEs is seen from an innovation perspective.

H4: Adoption of IEBT has a positive impact on Social Media Marketing

\subsection{Social Media Marketing}

Social media is categorized as the initiation of web development and design, which aims to enable communication, sharing of source information, and collaboration among users (Lee et al., 2016; Ahmad et al., 2018, Chatterjee \& Kar, 2020). In general, consumers are accustomed to spending more than
330 minutes per day participating in social media platforms. These platforms have become easy instruments to create online communication between consumers and companies, or between consumers and consumers worldwide, especially for SMEs Indonesia (Mayasari, 2019). Social media marketing allows users to receive each other's effective information about events around the world (Alnaser et al., 2020) includes pandemics such as Coronavirus as well. By utilizing SMM as a communication and interaction, we can attract audiences, providing them with important information about the spread and cessation of the Coronavirus. Through social media, a company can easily build its brand to increase its business activity (Cestyakara, 2013; Martyr \& Gambett, 2013; Odoom et al., 2017). Thus, social media marketing helps SMEs in Indonesia to encourage them to invest more in digital marketing (Chatterjee \& Kar, 2020; Mayasari, 2019; Iqbal et al., 2020).

\section{Research Methods and Materials}

\subsection{Study Design}

This study adopted a quantitative method with a structural equation modeling (SEM)-based variance partial least square (PLS) to enhance understanding on how financial support, perceived benefits, and external pressure relate to SMM as well as examining the mediating role of the adoption of IEBT (See Figure 1).

The respondent of this study were SMEs owners in Malang of East Java in Indonesia, selected using a convenience random sampling method. Some 130 SME owners were involved in this research and we found about seven questionnaires returned were incomplete. Therefore, we used 123 questionnaires for further analysis using SEM-PLS. The demographics of respondents was male $(65 \%)$ and female $(35 \%)$ (see Table 1$)$.

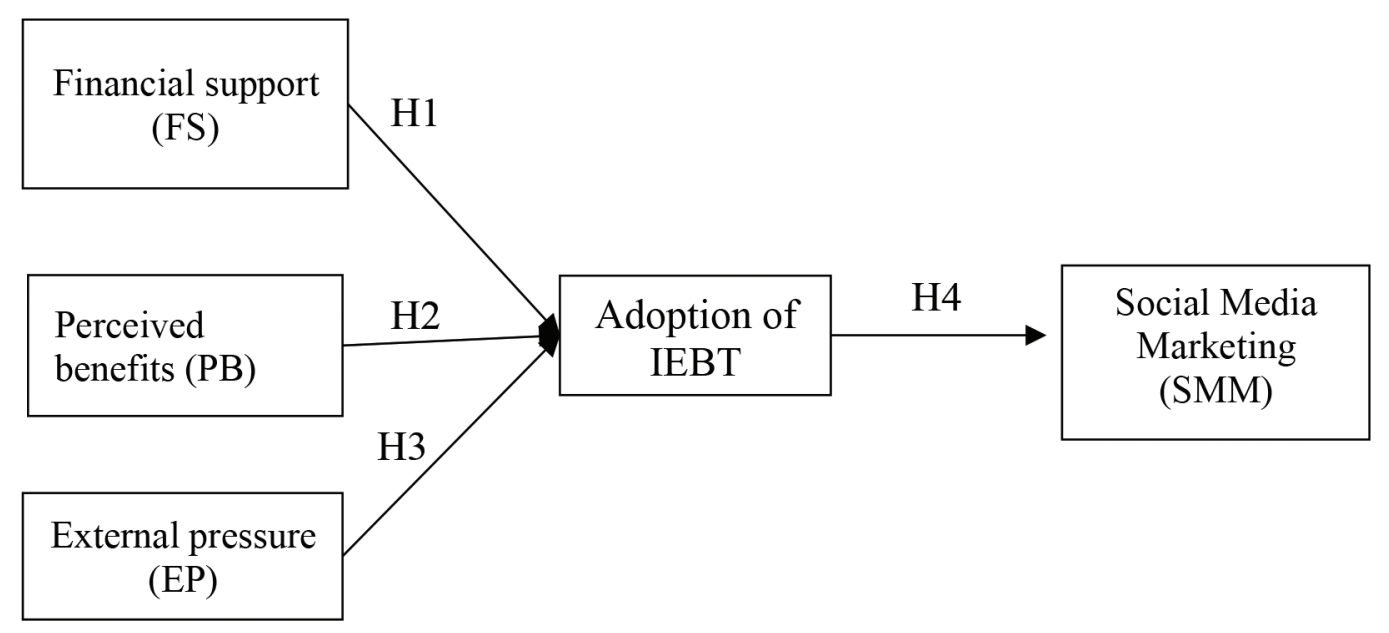

Figure 1: Theoretical Framework 
Table 1: The demographics of respondents

\begin{tabular}{|c|c|c|c|}
\hline S/No. & Characteristics & Frequency & Percentage \\
\hline \multirow[t]{3}{*}{1.} & Gender & & \\
\hline & Female & 43 & 35 \\
\hline & Male & 80 & 65 \\
\hline \multirow[t]{4}{*}{2.} & Business area & & \\
\hline & Restaurant & 59 & 48 \\
\hline & Service & 44 & 36 \\
\hline & Fashion & 20 & 16 \\
\hline \multirow[t]{6}{*}{3.} & No of years in the current company & & \\
\hline & $>10$ years & 29 & 24 \\
\hline & $7-9$ years & 18 & 15 \\
\hline & $4-6$ years & 29 & 24 \\
\hline & $1-3$ years & 29 & 24 \\
\hline & $<2$ years & 18 & 15 \\
\hline \multirow[t]{6}{*}{4.} & Educational Background & & \\
\hline & Senior High School & 61 & 50 \\
\hline & Diploma & 13 & 11 \\
\hline & Bachelor degree & 33 & 27 \\
\hline & Postgraduate degree & 9 & 7 \\
\hline & Certificate level & 7 & 6 \\
\hline \multirow[t]{4}{*}{5.} & No. of employees & & \\
\hline & $1-4$ & 94 & 76 \\
\hline & $5-19$ & 26 & 21 \\
\hline & $20-99$ & 3 & 2 \\
\hline \multirow[t]{5}{*}{6.} & Revenue per year (IDR) & & \\
\hline & $\leq 100$ Million & 81 & 66 \\
\hline & $>100-200$ Million & 25 & 20 \\
\hline & $>200-300$ Million & 15 & 12 \\
\hline & > 300 Million & 2 & 2 \\
\hline
\end{tabular}

\subsection{Measurement Development}

The questionnaire in this study was adapted from Chong and Pervan (2007); Ifinedo (2011), which includes financial support consisting of three indicators and perceived benefits, contains six indicators. Additionally, external pressure consists of six indicators, while the adoption of IEBT includes four indicators. Social media marketing is explained by three indicators from Chatterjee and Kar (2020). Respondents were asked to respond using a fivepoint Likert scale, ranging from 1 "strongly disagree" to 5 "strongly agree".

\section{Results and Discussion}

\subsection{The Outer Model Assessment}

The first step in evaluating external models seeks to verify whether the instrument is reliable or not. According to Hair et al. (2014) a good construct reliability should range from 0.6 to 0.8 . In this study, we performed two tests for validity using convergent validity (AVE $\geq 0.50)$ and discriminant validity. Table 2 shows that the CR scores of each construct range from 0.864 to 0.935 , which implies that the reliability of the construct is satisfied. However, the convergence 
validity calculation for several indicators (PB1, PB2, PB3, EP1, and EP2) must be omitted due to the item loading, which is less than 0.7. After elimination, all items had a load higher than 0.6, and the AVE value for each construct ranged from 0.680 to 0.827 above the recommended value of 0.5 , thus, the validity of convergence is met.

Table 3 shows the discriminant validity test where items differentiate between constructions or measure different concepts. The AVE for each component must be higher than the correlation square between the component and all other items (Fitch et al., 2005). On the other hand, the research model is considered to have good discrimination when the correlation between item is lower than the AVE square root (Fornell \& Larcker, 1981).

\subsection{Assessment of Structural Model}

All data of this study were calculated by employing 500 bootstrapped samples through 123 cases. The Coefficient of
Variance Inflation Factor (VIF) is greater than 5.00 (Hair et al., 2014). The test calculation shows that the inner range of VIF ranges 1.370-4.773, which implies that there is no collinearity.

\subsubsection{Path Coefficient}

We use path coefficients to determine the structural models. T-statistics were calculated using the bootstrap resampling process. According to Hair et al. (2013), a bootstrap procedure is a non-parametric approach to estimating the accuracy of PLS-SEM estimation. In this study, we ran all the data using 500 bootstrap samples. As shown in Table 3, all hypotheses are significant because the range of $\mathrm{p}$-value for each correlation is ranging from 0.00 to 0.033 , less than 0.05 (see Figure 2 and Table 4). From Table 4 , it can be seen that the first hypothesis was rejected, while the three other hypotheses were accepted.

Table 2: Results of Measurement (Outer) Model

\begin{tabular}{|c|c|c|c|c|c|}
\hline Construct & Item & Loading & $\begin{array}{c}\text { Cronbach } \\
\text { Alpha }(\alpha)\end{array}$ & CR & AVE \\
\hline \multirow{3}{*}{$\begin{array}{l}\text { Financial support } \\
\text { (FS) }\end{array}$} & Fs1 & 0.708 & \multirow{3}{*}{0.767} & \multirow{3}{*}{0.864} & \multirow{3}{*}{0.680} \\
\hline & Fs2 & 0.882 & & & \\
\hline & Fs3 & 0.873 & & & \\
\hline \multirow[t]{3}{*}{ Perceived benefits (PB) } & $\mathrm{pb} 4$ & 0.877 & \multirow{3}{*}{0.810} & \multirow{3}{*}{0.887} & \multirow{3}{*}{0.725} \\
\hline & pb5 & 0.903 & & & \\
\hline & $\mathrm{pb} 6$ & 0.769 & & & \\
\hline \multirow{4}{*}{$\begin{array}{l}\text { External pressure } \\
\text { (EP) }\end{array}$} & EP3 & 0.867 & \multirow{4}{*}{0.880} & \multirow{4}{*}{0.916} & \multirow{4}{*}{0.732} \\
\hline & EP4 & 0.879 & & & \\
\hline & EP5 & 0.829 & & & \\
\hline & EP6 & 0.845 & & & \\
\hline \multirow[t]{4}{*}{ Adoption of IEBT } & IEBT1 & 0.733 & \multirow{4}{*}{0.867} & \multirow{4}{*}{0.911} & \multirow{4}{*}{0.719} \\
\hline & IEBT2 & 0.866 & & & \\
\hline & IEBT3 & 0.891 & & & \\
\hline & IEBT4 & 0.893 & & & \\
\hline \multirow{3}{*}{$\begin{array}{l}\text { Social Media } \\
\text { Marketing (SMM }\end{array}$} & SSM1 & 0.884 & \multirow{3}{*}{0.896} & \multirow{3}{*}{0.935} & \multirow{3}{*}{0.827} \\
\hline & SSM2 & 0.945 & & & \\
\hline & SSM3 & 0.899 & & & \\
\hline
\end{tabular}

Table 3: Discriminant Validity

\begin{tabular}{|l|c|c|c|c|c|}
\hline & EP & FS & IEBT & PB & SMM \\
\hline EP & 0.855 & & & & \\
\hline FS & 0.737 & 0.825 & & & \\
\hline IEBT & 0.692 & 0.699 & 0.848 & & \\
\hline PB & 0.692 & 0.705 & 0.782 & 0,852 & 0,910 \\
\hline SMM & 0.650 & 0.683 & 0.623 & 0,625 & 0,9 \\
\hline
\end{tabular}


Table 4: Path Coefficients and Results of Hypotheses Testing

\begin{tabular}{|l|c|c|c|c|c|}
\hline Hypotheses & Relationship & Beta & T-value & P-values & Decision \\
\hline $\mathrm{H}_{1}$ & FS $\rightarrow$ IEBT & 0.101 & 1.183 & 0.237 & Rejected \\
\hline $\mathrm{H}_{2}$ & PB $\rightarrow$ IEBT & 0.531 & 6.683 & 0.000 & Accepted \\
\hline $\mathrm{H}_{3}$ & EP $\rightarrow$ IEBT & 0.304 & 4.112 & 0.000 & Accepted \\
\hline $\mathrm{H}_{4}$ & IEBT $\rightarrow$ SMM & 0.623 & 8.716 & 0.000 & Accepted \\
\hline
\end{tabular}

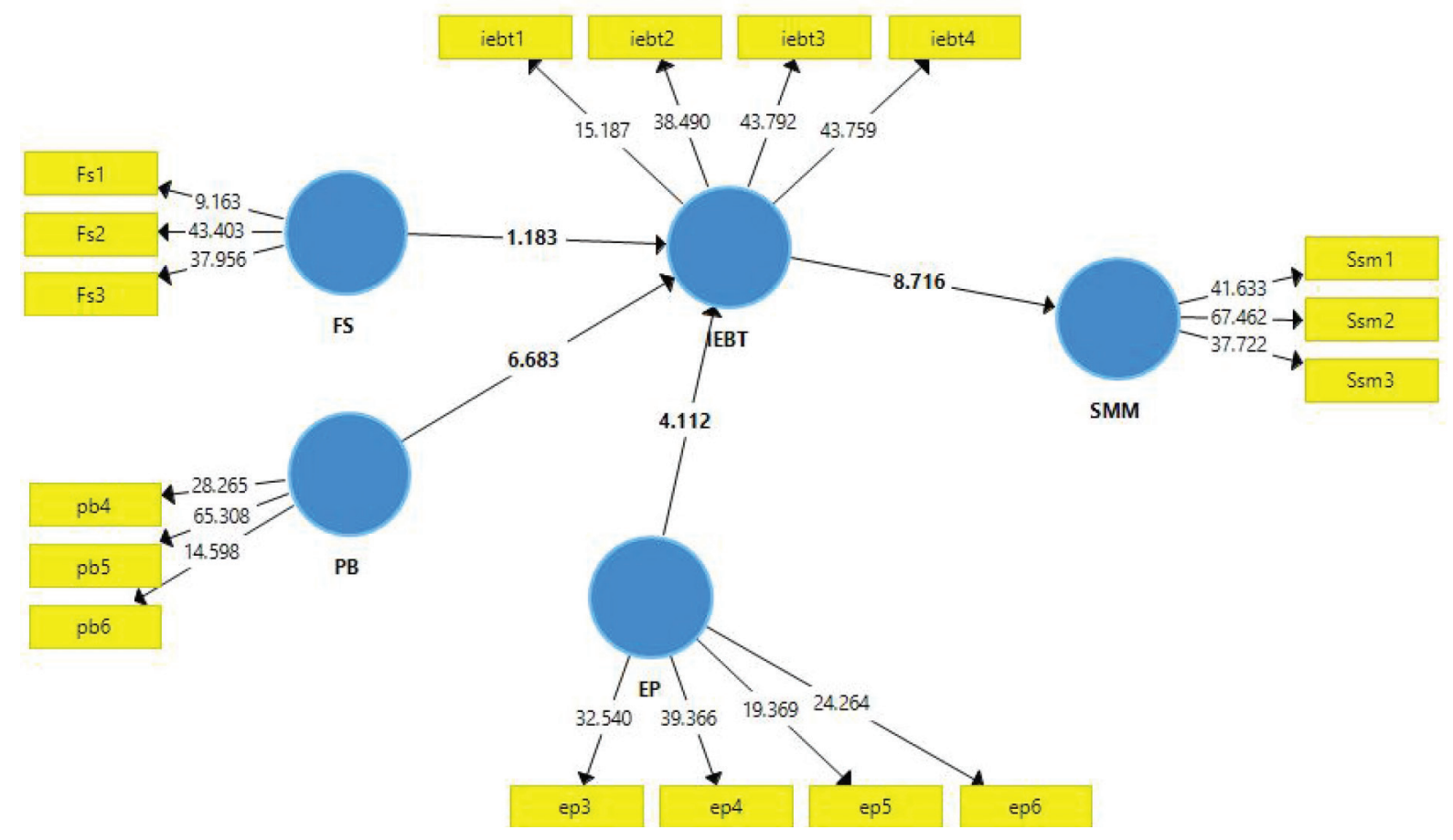

Figure 2: The structural equation modelling calculation

\subsubsection{Model Fit}

According to Hair et al. (2014), the R-square model shows the model prediction accuracy with the criteria of 0.75 (substantial), 0.50 (moderate), and 0.25 (weak). The calculation indicated that FS, PB and EP explain 69.5 percent of the IEBT variance, a moderate degree of predictivity. Further, FS, PB, EP, and IEBT describe 38.8 percent of SMM variance, a weak predictivity level. On the other hand, $\mathrm{f}^{2}$ effect size test was applied to estimate whether exogenous construction has a substantive impact on endogenous construction. According to Hair et al. (2014), $\mathrm{f}^{2}$ has three main values $0.02,0.15$, and 0.35 each represents small, medium, and large, respectively, influencing exogenous construction on endogenous construction. The range of $\mathrm{f}^{2}$ is ranging from 0.600 to 0.634 . In more detail, the effect size of FS, PB and EP on IEBT has a significant effect (f2 value is 0.600). However, the size of the effect of FS, PB, EP, and IEBT on SMM is at a large level (f2 value 0.634 ).

\subsection{The Relationship Between Variables}

The findings of this present test the four hypotheses proposed. The first hypothesis asserts that there is a direct positive influence of financial support on the adoption of IEBT. The results of the study found that $\mathrm{H} 1$ was not significant with the p-value of $0.237>0.05$ and the $t$-value of $1.183<1.96$, which implies that financial support did not influence the adoption of IEBT. This is due to the fact that the current financial support for SMEs with the existence of underlying institutions, for instance, banks that provide financial support to SMEs who want to use e-business technology. In fact, they are still constrained by administrative requirements such as not being able to 
make financial statements of their business, lack of credit access knowledge at fly and bureaucracy, which is still considered too difficult for them (Easterly, 2002). If they get adequate support from local banks, then they must be obedient in running an e-business-based business while they are constrained by the lack of quality human resources that understand e-business. Because their knowledge is still low on e-business engagement, companies actually easily get information from their banks and financial institutions. With such conditions, participants in this study point to the fact that financial support does not affect the adoption of IEBT. The findings of this research do not support the findings by Rajh et al. (2017); Ramadani et al. (2016); Ramayah et al. (2016). This rather contradictory result may be due to the insufficient knowledge of accessing funding from governments, banks, and other financial institutions. It is still little and there is reluctance to cope with IEBT in their work system.

The second hypothesis asserts that there is a direct positive influence of perceived benefits on the adoption of IEBT. The study results found that $\mathrm{H} 2$ is significant with the p-value $0.00>0.05$ and the t-value of $6.683(0>1.96)$; this result showed that perceived benefits affect the adoption of IEBT. In such a situation, participants believe that perceived benefits influence the adoption of IEBT. Since the perceived benefits for SMEs are in the form of adoption of Internet/ e-business technology, it will lead to profits by using IEBT through social media Internet/e-business. Internet/ e-business technology will eventually help increase return on investment (ROI), and with this IEBT they can market products at an affordable price and get cheaper raw material prices. The adoption of IEBT will drive to the direct and indirect costs reduction in the business. SMEs also benefit in improving their business processes. IEBT adoption has been able to help serve customers better with a faster 24-hour response. IEBT will help SMEs to work better with their suppliers. With such conditions, participants perceived benefits affect the adoption of IEBT. The results of this study reinforce the preliminary work by Almahamid and Awsi (2015); Chittenden and Ambler (2015); Chong and Pervan (2007). This condition is reasonable because SMEs have learned to adopt Internet technology by applying it to their business activities.

The third hypothesis asserts that there is a direct positive influence of external pressure on the adoption of IEBT. From the statistical calculation, the study found that $\mathrm{H} 3$ is significant with the p-value $0.000>0.05$ and t-value 4.112> 1.96. This result showed that external pressure affects the adoption of IEBT. In such a situation, for participants external pressure affects the adoption of IEBT. Due to external pressure at SMEs, some of their competitors have been adopting Internet technology in managing their ventures. Their competitors recognize the importance of IEBT and use it for their business activities. They also realize that SMEs customers are ready to do business over the Internet with social media applications. Their customers also demand the use of IEBT in their business due to social distancing rules. SMEs partners demand the use of IEBT in doing business with them. Further, SMEs' suppliers and partners are ready to do business over the Internet. With such conditions, participants see that external pressure affects the adoption of IEBT. The finding of this work confirms the previous study by Chong and Pervan (2007); Hart and Saunders (1997); Kula and Tatoglu (2003); Poon and Swatman (1999). External pressure on SMEs is currently from some of their competitors who are already adapting IEBT in running their business

The fourth hypothesis asserts that there is a direct positive influence of the adoption of IEBT on SMM. From prior calculation, it is shown that the p-value $0.000>0.05$ and the t-value is $8.716(>1.96)$. The result of this study confirmed that the adoption of IEBT affects SMM. In such a situation, participants see that the adoption of IEBT affects SMM. They also use IEB e-commerce/e-payment, at all times, for their transactions. SMEs also use the IEB for their critical operations. The need to adopt IEBT for their business operations and business activities is high. Participants see that adoption of IEBT affects SMM. The results of this study support the findings by Ahmad et al. (2018); Childers et al. (2019); Bailey, (2019); Chatterjee and Kar (2020). With the advent of SMM, SMEs are starting to advertise their products and services through social media, which they feel is very helpful in generating more profits for their business.

\section{Conclusions}

This paper aims to explore how financial support, perceived benefits, and external pressure determine social media marketing as well as examine the emerging role of IEBT in supporting this relationship. The findings show that perceived benefits and external pressure positively affect the adoption of IEBT and social media marketing. However, financial support failed to explain the adoption of IEBT. This study confirms that the adoption of IEBT has successfully mediated the influence of financial support, perceived benefits, and external pressure on SMM. Despite the fact that the findings showing that financial support do not significantly impact the adoption of IEBT, this means that SMEs funding access to business capital is still low. This is due to their inadequate knowledge of accessing funding from the government, banks, and other financial institutions. It is still little, as it their reluctance to cope with IEBT in their work system. First, college education about SMEs needs to provide comprehensive training and mentoring for SME entrepreneurs with technological information support to encourage and conduct accountable financial statements and marketing of IT-based products and services. Second, 
through the relevant services, the government can channel capitalization to SMEs in a more straightforward condition, making all SMEs accessible to funding. Third, financial institutions and banks should provide SMEs loan facilities. Fourth, information and communications offices can create digital platforms for SMEs' information access and promotion. Fifth, the Department of Industry and Commerce can assist with tools, materials, and practical training in an effective and efficient production process. This research's limitations is that it only include participants in East Java; Further research should involve SMEs throughout Indonesia to find characteristics and uniqueness in sustainability. However, this study can be a first step for research related to SMEs' sustainability, especially in Indonesia.

\section{References}

Abd Rahman, A., Singhry, H. B., Hanafiah, M. H., \& Abdul, M. (2017). Influence of perceived benefits and traceability system on the readiness for Halal Assurance System implementation among food manufacturers. Food Control, 73, 1318-1326. https://doi.org/10.1016/j.foodcont.2016.10.058

Ahmad, S. Z., Ahmad, N., \& Abu Bakar, A. R. (2018). Reflections of entrepreneurs of small and medium-sized enterprises concerning the adoption of social media and its impact on performance outcomes: Evidence from the UAE. Telematics and Informatics, 35(1), 6-17. https://doi.org/10.1016/j. tele.2017.09.006

Almahamid, S., \& Awsi, O. (2015). Perceived organizational ERP benefits for SMEs: Middle eastern perspective. Interdisciplinary Journal of Information, Knowledge, and Management, 10(January 2015), 145-172. https://doi.org/10.28945/2301

Alnaser, A. S., Habes, M., Alghizzawi, M., \& Ali, S. (2020). The Relation among Marketing ads, via Digital Media and mitigate (COVID-19) pandemic in Jordan The Relationship between Social Media and Academic Performance: Facebook Perspective View project Healthcare challenges during COVID-19 pandemic View project. Dspace.Urbe.University, July. https://www.researchgate.net/publication/342866347

Alshehhi, A., Nobanee, H., \& Khare, N. (2018). The impact of sustainability practices on corporate financial performance: Literature trends and future research potential. Sustainability, 10(2). https://doi.org/10.3390/su10020494

Ann, G. E., Zailani, S., \& Wahid, N. A. (2006). A study on the impact of environmental management system (EMS) certification towards firms' performance in Malaysia. Management of Environmental Quality: An International Journal, 17(1), 7393. https://doi.org/10.1108/14777830610639459

Aral, S., \& Weill, P. (2007). IT assets, organizational capabilities, and firm performance: How resource allocations and organizational differences explain performance variation. Organization Science, 18(5), 763-780. https://doi.org/10.1287/ orsc. 1070.0306
Bailey, A. (2019). Social Media: The Good, the Bad, and the Ugly. Plastic Surgical Nursing: Official Journal of the American Society of Plastic and Reconstructive Surgical Nurses, 39(3), 66. https://doi.org/10.1097/PSN.0000000000000271

Baresel-Bofinger, A., Ketikidis, P. H., Koh, S. C. L., \& Cullen, J. (2006). Implementation of Green Supply Chain Management in South-East Europe - A Literature Review. Wiley Online Library, 1-11. https://seerc.org/refbase/files/bareselbofinger/2006/314_Baresel-Bofinger_etal2006.pdf

Bayramov, V., Hasanov, R., Aghayarli, L., Kadyrov, Z., Aghahasanli, I., \& Isayev, S. (2019). A Comparative Study on Development of Small and Medium Enterprises (SMEs) in Azerbaijan. SSRN Electronic Journal, 99412. https://doi. org/10.2139/ssrn.3485576

Cestyakara, A. (2013). Social Media Adoption Model for Smart Entrepreneur. International Conference on ICT for Smart Society, 1-7.

Chang, M. K., \& Cheung, W. (2001). Determinants of the intention to use Internet/WWW at work: A confirmatory study. Information and Management, 39(1), 1-14. https://doi.org/10.1016/S03787206(01)00075-1

Chatterjee, S., \& Kar, A. (2020). Why do small and medium enterprises use social media marketing and what is the impact: Empirical insights from India. International Journal of Information Management, 53(December 2019), 102103. https://doi.org/10.1016/j.ijinfomgt.2020.102103

Chege, S. M., \& Wang, D. (2020). Information technology innovation and its impact on job creation by SMEs in developing countries: an analysis of the literature review. Technology Analysis \& Strategic Management, 32(3), 256-271.

Chelliah, T. D., Chelliah, M. K., \& Jaganathan, M. (2017). Adoption of corporate social responsibility: Empirical evidence from Malaysian SMEs. Jurnal Komunikasi: Malaysian Journal of Communication, 33(4), 174-189. https://doi.org/10.17576/ JKMJC-2017-3304-11

Childers, C. C., Lemon, L. L., \& Hoy, M. G. (2019). \#Sponsored \#Ad: Agency Perspective on Influencer Marketing Campaigns. Journal of Current Issues and Research in Advertising, 40(3), 258-274. https://doi.org/10.1080/10641734.2018.1521113

Chittenden, F., \& Ambler, T. (2015). A question of perspective: Impact Assessment and the perceived costs and benefits of new regulations for SMEs. Environment and Planning $C$ : Government and Policy, 33(1), 9-24. https://doi.org/10.1068/ c12211b

Chong, S., \& Pervan, G. (2007). Factors influencing the extent of deployment of electronic commerce for small-and medium-sized enterprises. Journal of Electronic Commerce in Organizations, 5(1), 1-29. https://doi.org/10.4018/jeco.2007010101

Cordes, J. J. (2017). Using cost-benefit analysis and social return on investment to evaluate the impact of social enterprise: Promises, implementation, and limitations. Evaluation and Program Planning, 64, 98-104. 
Dekker, R., Engbersen, G., Klaver, J., \& Vonk, H. (2018). Smart Refugees: How Syrian Asylum Migrants Use Social Media Information in Migration Decision-Making. Social Media and Society, 4(1). https://doi.org/10.1177/2056305118764439

Easterly, W. (2002). The cartel of good intentions: The problem of bureaucracy in foreign aid. The Journal of Policy Reform, 5(4), 223-250. https://doi.org/10.1080/1384128032000096823

Mayasari, I. K. (2019). "DEAR SIS" A Case Study on Trust Cultivation on Indonesian Facebook Online Craft Stores. Journal Communication Spectrum, 9(2), 79-94.

Nguyen, X. T., \& Luu, Q. K. (2020). Factors Affecting Adoption of Industry 4.0 by Small-and Medium-Sized Enterprises: A Case in Ho Chi Minh City, Vietnam. Journal of Asian Finance, Economics and Business, 7(6), 255-264. https://doi. org/10.13106/jafeb.2020.vol7.no6.255

Hair, S. M., Hopkins, L., \& Kuppelwieser, V. G. (2014). Partial least squares structural equation modeling (PLS-SEM) An emerging tool in business research. European Business Review. https://doi.org/10.1108/EBR-10-2013-0128

Hart, P. J., \& Saunders, C. S. (1997). Emerging electronic partnerships: Antecedents and dimensions of EDI use from the supplier's perspective. Journal of Management Information Systems, 14(4), 87-111. https://doi.org/10.1080/07421222.199 8.11518187

Hirsch, B., Nitzl, C., \& Schoen, M. (2018). Interorganizational trust and agency costs in credit relationships between savings banks and SMEs. Journal of Banking and Finance, 97(March 2020), 37-50. https://doi.org/10.1016/j.jbankfin.2018.09.017

Ifinedo, P. (2011). Internete-business technologies acceptance in Canada's SMEs. Internet Research, 21(3), 255-281.

Iqbal, M., Sucherly, S., Azis, Y., \& Kaltum, U. (2020). Innovation and Business Strategy at State-Owned Enterprises: Evidence from Indonesia. In: 4th International Conference on Management, Economics and Business (ICMEB 2019), 4, 155-159.

Kula, V., \& Tatoglu, E. (2003). An exploratory study of Internet adoption by SMEs in an emerging market economy. European Business Review, 15(5), 324-333. https://doi. org/10.1108/09555340310493045

Kumar, D., Samalia, H. V., \& Verma, P. (2017). Factors Influencing Cloud Computing Adoption by Small and Medium-Sized Enterprises (SMEs) In India. Pacific Asia Journal of the Association for Information Systems, 9(3), 25-48. https://doi. org/10.17705/1 pais.09302

Lee, J. W., Becker, K., \& Potluri, R. M. (2016). Antecedents of Corporate Adoption of Social Media and the Role of the Technology Acceptance Model in the Path. Journal of Asian Finance, Economics and Business, 3(2), 67-76. https://doi. org/10.13106/jafeb.2016.vol3.no2.67.

Mehrtens, J., Cragg, P. B., \& Mills, A. M. (2001). A model of Internet adoption by SMEs. Information and Management, 39(3), 165176. https://doi.org/10.1016/S0378-7206(01)00086-6
Moreira, S. (2018). Firm Dynamics, Persistent Effects of Entry Conditions, and Business Cycles. SSRN Electronic Journal. https://doi.org/10.2139/ssrn.3037178

Auwal, M. A., Mohamed, Z., Nasir Shamsudin, M., Sharifuddin, J., \& Ali, F. (2020). External pressure influence on entrepreneurship performance of SMEs: a case study of Malaysian herbal industry. Journal of Small Business and Entrepreneurship, 32(2), 149-171. https://doi.org/10.1080/08 276331.2018.1509504

Müller, J. M., \& Voigt, K. I. (2018). Sustainable Industrial Value Creation in SMEs: A Comparison between Industry 4.0 and Made in China 2025. International Journal of Precision Engineering and Manufacturing - Green Technology, 5(5), 659-670. https://doi.org/10.1007/s40684-018-0056-z

Nicola, M., Alsafi, Z., Sohrabi, C., Kerwan, A., Al-Jabir, A., Iosifidis, C., Agha, M., \& Agha, R. (2020). The socio-economic implications of the coronavirus pandemic (COVID-19): A review. International Journal of Surgery, 78(April), 185-193. https://doi.org/10.1016/j.ijsu.2020.04.018

Odoom, R., Anning-Dorson, T., \& Acheampong, G. (2017). Antecedents of social media usage and performance benefits in small- and medium-sized enterprises (SMEs). Journal of Enterprise Information Management, 30(3), 383-399. https:// doi.org/10.1108/JEIM-04-2016-0088

Poon, S., \& Swatman, P. M. C. (1999). An exploratory study of small business Internet commerce issues. Information and Management, 35(1), 9-18. https://doi.org/10.1016/S03787206(98)00079-2

Rajh, E., Budak, J., Ateljević, J., Davčev, L., Jovanov, T., \& Ognjenović, K. (2017). Entrepreneurial intentions in selected South-East European countries. Glasnik Srpskog Geografskog Društva, 592-610.

Ramadani, V., Dana, L. P., Gërguri-Rashiti, S., \& Ratten, V. (2016). Entrepreneurship and management in an Islamic context. Entrepreneurship and Management in an Islamic Context, 1-248. https://doi.org/10.1007/978-3-319-39679-8

Ramakrishnan, P., Haron, H., \& Goh, Y. N. (2015). Factors influencing green purchasing adoption for small and medium enterprises (smes) in malaysia. International Journal of Business and Society, 16(1), 39-56. https://doi.org/10.33736/ ijbs.552.2015

Ramayah, T., Ling, N. S., Taghizadeh, S. K., \& Rahman, S. A. (2016). Factors influencing SMEs website continuance intention in Malaysia. Telematics and Informatics, 33(1), 150-164. https://doi.org/10.1016/j.tele.2015.06.007

Rogers, E. M. (2010). Diffusion of innovations. In: Simon and Schuster, 24(3). https://doi.org/10.1007/s10460-007-9072-2

Sadowski, B. M., Maitland, C., \& Van Dongen, J. (2002). Strategic use of the internet by small- and medium-sized companies: An exploratory study. Information Economics and Policy, 14(1), 75-93. https://doi.org/10.1016/S01676245(01)00054-3 
Sumiati, S. (2020). Improving Small Business Performance: The Role of Entrepreneurial Intensity and Innovation. Journal of Asian Finance, Economics and Business, 7(10), 211-218. https://doi.org/10.13106/jafeb.2020.vol7.n10.211

Testa, F., Nucci, B., Iraldo, F., Appolloni, A., \& Daddi, T. (2017). Removing obstacles to the implementation of LCA among SMEs: A collective strategy for exploiting recycled wool. Journal of Cleaner Production, 156, 923-931. https://doi. org/10.1016/j.jclepro.2017.04.101

Walker, J. H., Saffu, K., \& Mazurek, M. (2016). An Empirical Study of Factors Influencing E-Commerce Adoption/Non-Adoption in Slovakian SMEs. Journal of Internet Commerce, 15(3), 189213. https://doi.org/10.1080/15332861.2016.1191049

Weisberg, J., Te'eni, D., \& Arman, L. (2011). Past purchase and intention to purchase in e-commerce. Internet Research., 21(1), 82-96. https://doi.org/10.1108/10662241111104893

Yoshino, N., Taghizadeh-Hesary, F., Charoensivakorn, P., \& Niraula, B. (2016). Small and Medium-Sized Enterprise (SME) Credit Risk Analysis Using Bank Lending Data: An Analysis of Thai SMEs. Journal of Comparative Asian Development, 15(3), 383-406. https://doi.org/10.1080/15339 114.2016.1233821 